\author{
Branko Bošnjaković ${ }^{1}$ \\ Château de Tannay, CH-1295 Tannay, Switzerland \\ Tel: 0041227769416; Email: branko.bosnjakovic@bluewin.ch
}

\title{
Europe Between Climate and Energy Insecurity: Geopolitical Aspects
}

\begin{abstract}
EU sees itself as a world leader in coping with the challenge of climate change. At the same time, the Ukraine crisis has demonstrated how vulnerable its energy supply security is due to EU's dependence on import oil and gas. The paper addresses the interlinkages and prospects of EU's climate and energy policies with respect to ethical and security dimensions. The ethical dimension is addressed in terms of how to fairly allocate responsibility among nations, regions and states to reduce GHG emissions to non-dangerous levels, a central issue at the upcoming UN summit in Paris. The proposed principles, such as the common but differentiated responsibility, are discussed in view of a growing literature, political controversies and converging diplomatic moves. At the same time the fundamental values of the EU may be at stake if the security dimension of all EU member states cannot be guaranteed. Both ethical and security challenges EU is confronted with points strongly towards accelerated introduction of a low-carbon economy and corresponding infrastructure, with renewables to play a central role in the medium/long term. A review of the literature shows that continuing import dependence on oil and gas, including from Russia, is a risk factor both in economic, political and environmental terms. Some recently proposed policy responses, such as the creation of an EU energy union, are reviewed and critically evaluated.
\end{abstract}

Key words: Climate, Energy, EU, Geopolitics

\section{Introduction: European Union as the leading "soft" world power}

The precursor of the present European Union was the European Economic Community, established in 1957, when the founding members, during the Intergovernmental Conference on the Common Market and Euratom, adopted the Treaties of Rome. Since then, the EU has established and extended an unprecedented economic and peace order in a large part of Europe based on a culture of transnational cooperation and solidarity. At the same time, extensive EU legislation and policies have

1 Dr. Bošnjaković is former Regional Adviser for Environment of the UN Economic Commission for Europe, Geneva. 
been developed ensuring the respect and implementation of a range of basic values and principles. To join the EU, a new Member State must meet three criteria: (1) political: stability of institutions guaranteeing democracy, the rule of law, human rights and respect for and protection of minorities; (2) economic: existence of a functioning market economy and the capacity to cope with competitive pressure and market forces within the Union; (3) acceptance of the Community acquis: ability to take on the obligations of membership, including adherence to the aims of political, economic and monetary union. The prosperity and the unique economic and peace order of the European Union have exercised up to now an irresistible attraction to an increasing number of European countries, wishing to join the Union.

Whereas the environmental protection was not at stake at the time of the adoption of the Treaties of Rome, resources and energy security issues definitely were. Testimony to that are the European Coal and Steel Community (1951) and the Euratom (1957). The development of the EU environmental and climate policy since the1970s, its impact both at the national and at the pan-European levels, as well as the emergence of the EU as a world environmental leader, has been broadly described and discussed by the author [1].

Both with respect to the climate change policy, as well as to the energy security policy, the EU has been confronted again and again with ethical and geopolitical aspects. The present paper, largely an updated version of a previous publication by the author [2], attempts to take stock of the recent developments of EU climate and energy policies, taking into account the ongoing power shifts taking place world-wide and at the pan-European level, and how they pose considerable challenges to the individual EU member states, and to the EU as a whole.

\section{Political and ethical dimensions of climate policy at the global level}

The global development of the climate policy has given little reason for optimism so far. The initial hopes connected with the Kyoto Protocol under the United Nations Framework Convention on Climate Change UNFCCC (with the second commitment period ending in 2020) have evaporated since the global GHG emissions grew by more than $60 \%$ in the last 20 years. After the the Copenhagen conference in 2009, seen by many as failure[3], all eyes are focused now on the world climate summit to be held in Paris in December 2015 where a credible and convincing successor agreement to the Kyoto Protocol should be negotiated. The Copenhagen conference demonstrated how geopolitical interests of governments prevailed over the ethical ones. Whereas the EU was striving to achieve consensus on binding emission limits for all countries, the biggest emitters, USA and China in particular did not consent.

In the meantime, the Intergovernmental Panel on Climate Change (IPCC) has in its latest report articulated, for the first time in depth, the significance of the ethical, justice, and equity issues entailed by climate change [4]. It contains to date possibly 
the most elaborated clarification of concepts and methods in ethics that are relevant to climate change. Two main issues confronting societies are: what constitutes dangerous interference with the climate system and how to deal with. Ethics involves questions of justice and value. Economic tools and methods can be used in assessing the positive and negative values that result from particular decisions, policies, and measures. The IPCC argues that effective climate change mitigation will not be achieved if each agent (individual, institution or country) acts independently in its own selfish interest, suggesting the need for collective action. Some adaptation actions, on the other hand have characteristics of a private good as benefits of actions may accrue more directly to individuals, regions, or countries that undertake them. Nevertheless, financing such adaptive activities remains a major issue, particularly for poor individuals and countries. From a public good perspective, global coordination may be less important for many forms of adaptation than for mitigation. Analysis contained in the literature of moral and political philosophy can contribute to understanding ethical questions that are raised by climate change, including: how much overall climate mitigation is needed to avoid "dangerous interference"; how the effort or cost of mitigating climate change should be shared among countries and between the present and future; how to account for such factors as historical responsibility for emissions; and how to choose among alternative policies for mitigation and adaptation. Ethical issues of wellbeing, justice, fairness, and rights are all involved. Duties to pay for some climate damages can be grounded in compensatory and distributive justice. From the perspective of countries rather than individuals or groups of individuals, historic emissions can help determine causal responsibility for climate change. The IPCC report [4] does not attempt to answer ethical questions, but rather provides policymakers with the tools: concepts, principles, arguments, and methods.

Numerous academic papers on climate justice were written in the wake of the Copenhagen conference 2009. Müller, Höhne and Ellerman [5] consider the politically sensitive issue of differentiating (historic) responsibility for, and not merely (causal) contribution to climate change. They highlight the fact that, while related, the two issues ('contribution to' and 'responsibility for') are fundamentally different and should not be confused. They also propose a methodology for calculating shares of responsibility as opposed to the shares in causal contribution. The rather large difference between the responsibilities under both conceptions gives pause for thought as to what sorts of burdens can justly be demanded in any application of the UNFCCC principle of common but differentiated responsibilities.

The cumulative sum of a country's historical emissions is one indicator that tries to capture the contribution a country has made to the climate change problem. In most cases a country's historic share of global emissions differs from its current share. For most industrialized countries, the historic share is higher, in many cases significantly so. Baumert et al. [6] discuss various approaches how to assess historic contributions. The outcomes depend on many assumptions, in particular whether $\mathrm{CO}_{2}$ from landuse change is taken into account, and the time period chosen. Proposals that rely on 
historical emissions prior to 1990 are unlikely to receive widespread support, in part due to data constraints. No official country-level data exists prior to 1990. Baumert et al. conclude "that it is unlikely that this concept can form the core of an agreement, or could be assessed in a manner reliable enough to be the basis for legal obligations".

Dellink at al. [7] argue that climate change may cause most harm to countries that have historically contributed the least to greenhouse gas emissions and land-use change. They identify 'consequentialist' and 'non-consequentialist' ethical principles to guide a fair international burden-sharing scheme of climate change adaptation costs. Using these ethical principles, they derive political principles - historical responsibility and capacity to pay - that can be applied in assigning a share of the financial burden to individual countries. They then propose a hybrid 'common but differentiated responsibilities and respective capabilities' approach as a promising starting point for international negotiations on the design of burden-sharing schemes. A numerical assessment of several scenarios shows that the countries of Annex I of the UNFCCC would bear the bulk of the costs of adaptation, but respective contributions differ substantially subject to the choice of a capacity to pay indicator. Assuming costs of climate adaptation of USD 100 billion per year, the total financial contribution by the Annex I countries would be in the range of USD 65-70 billion per year, giving a range of USD 43-82 per capita per year [7].

More recently, Leal-Arcas [8] argues that a more effective (and presumably fairer) way to tackle climate change today is by bringing on board the major GHG emitters, irrespective of their GDP, and asking them to reduce their GHG emissions in an equitable manner without ignoring the historic responsibilities on the part of developed countries. The Kyoto Protocol's stipulation that only Annex I countries reduce their GHG emissions does not reflect today's or tomorrow's climate change reality, nor is it acting fast enough to reduce GHG emissions at the agreed levels. It is not enough to ask only Annex I countries to reduce their GHG emissions if the aim is to solve the climate change issue. This means the BRICS countries (Brazil, Russia, India, China, and South Africa) are part of the solution to climate change mitigation. Climate change will have a significant impact on the BRICS. Conversely, the expected impact of the BRICS on climate change is considerable. The size and rate of growth of the BRICS's economies, of their energy demand, of their energy imports (for instance, in the case of China and India), and of their atmospheric emissions of various types make these countries essential major partners in any regional or global discussions relating to climate change or the production and consumption of energy.

However, the BRICS states have very different attitudes towards the issue of climate change, and how to cope with it. Whereas Russia, one of the biggest exporters of fossile fuels, may hope that climate change will bring even economic and political advantages [9], China and India are net importers of fossile based energy and more motivated to develop renewable sources. A report by the International Energy Agency (IEA) has developed a matrix that situates climate change mitigation efforts of countries in the global context according to the national energy security concerns and proactive 
measures to harness benefits of renewable energy technologies [10]. The key point is that deployment of renewables - a key factor in climate change mitigation efforts depends critically on two factors: the GDP and the energy import dependence. With regard to the change of energy import dependence over time, countries can be grouped into four categories: (a) stable importers that try to contain or reduce dependence (Germany); (b) former exporters that try not to become dependent (China); (c) former importers that were successful in becoming independent (Denmark); (d) exporters that are not concerned due to large resources (Russia). Correspondingly, as described by Holslag [11], "the Chinese government clearly intends to close existing technology gap in the coming decade".

Neither the IPCC nor the numerous academic analyses have provided ready-made solutions - there will be no climate justice without corresponding negotiations at the inter-governmental level. The process of negotiating a global climate agreement for the post- 2020 period aims to limit the rise of the global average temperature to below 2 degrees above pre-industrial levels. A key component of these negotiations will be the Intended Nationally Determined Contributions (INDCs), or national plans for action on climate change, as requested by UNFCCC from all signatories. Developed countries propose that the INDCs must focus on mitigation, have robust transparency and Monitoring, Reporting and Validation (MRV) mechanisms, and that all parties including developing countries should commit to emissions targets. Developing countries on the other hand express that INDCs should vary according to national circumstances and include climate change adaptation. They also propose that developed countries should lead the process, and include support to developing countries for capacity building, technology and climate finance. After an initial lack of clarity of what constitutes an INDC, developing countries are beginning to understand that the main focus of INDCs should be a country's contribution towards a global mitigation goal, which can be framed as a reduced growth in emissions for developing countries [12].

All nations were requested to submit an INDC before the end of March 2015, with an absolute deadline of end October. By October 6, 2015, there have been 110 submissions from 137 countries (EU combines 28 countries in 1 submission) [13]. However, the most significant step was the Joint Announcement on Climate Change by the US President Obama and China's President Xi, in November 2014, and the recent US-China Joint Presidential Statement in September 2015 with new policy commitments and a common vision for an ambitious global climate agreement in Paris [14]. The US is committed to reduce its overall GHG emissions by 26 to $28 \%$ until 2025 in comparison with 2005; China took up the obligation to reduce its carbon intensity $\left(\mathrm{CO}_{2}\right.$ emissions per unit of economic output) by 60 to $65 \%$ until 2030 in comparison with $2005[15,16]$.

The Climate Action Tracker (CAT) is an independent scientific analysis produced by four research organisations tracking climate action and global efforts towards the globally agreed aim of holding warming below $2{ }^{\circ} \mathrm{C}$, since 2009 [17]. It concludes that submissions made until early October cover $86 \%$ of global emissions in 2010 
and $86 \%$ of global population. Some INDCs assessed by CAT so far include ratings for the EU (medium), USA (medium), Russian Federation (inadequate), Canada (inadequate), Ethiopia (sufficient), China (medium with inadequate carbon intensity target), South Korea (inadequate), Japan (inadequate), Australia (inadequate), South Africa (inadequate). CAT concludes that "the unconditional pledges or promises that governments have made, as of 1 October 2015 , would limit warming to 2.5 to $2.7^{\circ} \mathrm{C}$ above pre-industrial levels. In other words, there is still a substantial gap between what governments have promised to do and the total level of action they have undertaken to date".

\section{Towards an EU 2030 climate package: challenges, dilemmas and dividing lines}

Whereas the outcomes of the 2015 Paris summit look hopeful but still uncertain, the European Commission proposed in January 2014 a "Policy framework for climate and energy in the period from 2020 to 2030" [18], and the EU Council adopted in October 2014 the "2030 Climate and Energy Policy Framework" [19]. The two documents maintain EU's ambitious role when coping with the challenges of climate change. They reflect not only the different positions among Member States, but also the impact of the dramatic developments in the neighbouring Ukraine. As far as the $\mathrm{CO}_{2}$ emission target is concerned, the division lines run roughly between Eastern European countries led by Poland (advocating a less stringent target), the Western and Scandinavian countries, which are in favour of sharp, nationally binding targets, while France is (still) endorsing nuclear energy ${ }^{1}$, and Germany and Denmark demand additional policies favouring renewable and corresponding investments in electricity networks [21]. The impact of the events in the Ukraine, and the vulnerability of the EU due to its dependence on the energy imports from Russia, will be addressed in detail in subsequent chapters.

The 2030 Climate and Energy Policy Framework may be seen as an intermediate step between the 2020 package (abbreviated as 20-20-20 targets, presently under implementation), and the very ambitious European ambitions for reaching in 2050 80\% to $95 \%$ less $\mathrm{CO}_{2}$ emissions than in 1990, as presented in the EU 2050 Roadmap [22].

Before turning to the 2030 policy framework, let us consider the achievements of the current 2020 package. The Union has set itself three targets to be attained by 2020 for greenhouse gas emissions reductions $(20 \%)$, the share of renewable energy $(20 \%)$ and improvements in energy efficiency (20\%). Progress towards these 20/20/20 targets includes [18]:

$1 \quad$ The French minister responsible for the environment, Ségolène Royal, announced the greening of the energy sector, implying that the nuclear contribution to electricity production should be reduced from $75 \%$ now to $50 \%$ in 2025 [20]. 
- Greenhouse gas emissions in 2012 decreased by $18 \%$ relative to emissions in 1990 and are expected to reduce further to $24 \%$ lower than in 1990 by 2020.

- The share of renewables in final energy consumed has increased to $13 \%$ in 2012 and is expected to rise further to $21 \%$ in 2020.

- The EU had installed about $44 \%$ of the world's renewable electricity (excluding hydro) at the end of 2012.

- The energy intensity of the EU economy was reduced by 24\% between 1995 and 2011 whilst the improvement by industry was even $30 \%$.

- Less successful has been progress in improving energy efficiency [23]: energy savings will amount to $18-19 \%$ in 2020 , with one third of this progress due to the lower than expected growth during the financial crisis.

The political process within the EU leading to the adoption of the 2030 target for renewables and for the emissions reduction revealed two main dividing lines.

\section{First dividing line: renewables' target}

In the recent years, renewable energy has been a great success world-wide but in some ways also a disappointment, depending on the point of view. It was a success, because in 2013 it contributed nearly a half of all newly installed energy production capacity [24]. Its contribution rose from $7.8 \%$ to $8.5 \%$ in 2013 alone, corresponding to world-wide investments of 214 billion US\$. It was a disappointment, because worldwide investments into renewables decreased in two subsequent years 2012 and 2013. Investments in the EU went down by $44 \%$ to 48 billion $\$$ in 2012 only, whereas in 2013, China invested 56 billion US\$, thus becoming world head runner. Whereas the cost price of solar and wind electricity has been decreasing sharply since 2009, both sources are still dependent on state subsidies. At the same time, it should be kept in mind that worldwide annual subsidies for fossil energy are still in the order of 500 billion US\$.

Renewables' possible contribution to the $\mathrm{CO}_{2}$ emission reduction has disappointed recently both at the world and the EU level. At the world level, because renewables' growth could not compensate the even larger growth of fossil utilisation in the rapidly growing emerging economies. In the EU, the initially spectacular role of renewables has been slowing down for some very specific reasons that can be exemplified by the development in its largest economy - Germany [25].

The German energy policy concept Energiewende of 2010 decided to phase out nuclear energy and introduced a number of ambitious quantitative targets on GHG emissions reduction relying heavily on the role of renewables. It was based on a number of political and societal motivations: (1) improve prospects for industry and employment; (2) ensure energy supply security; (3) reduce GHG emissions; (4) profitability; (5) ethical considerations.

The German sustainable energy policy has been confronted with several serious problems since 2012: (1) increasing subsidy costs of renewable electricity and how to 
allocate them; (2) consequences of the rapidly increasing solar and wind contributions for the functioning of the electricity market; (3) increasing GHG emissions from the electricity sector. An additional root problem with renewable electricity is (4) inadequacy, in both qualitative and quantitative terms, of the present transmission and distribution networks, and of storage capacities, to cope with the rapid extension of the renewable electricity. The fluctuating and irregular production of solar and wind electricity was causing repeatedly destabilisation of electric grids, thus increasing the risk of damage to industrial installations. In Germany the incidence of grid perturbations increased by $30 \%$ between 2010 and 2013 [26].

In one way or another, several EU Member States like Spain and Italy have been experiencing similar problems with the subsidised introduction of renewable energy [27]. Recent proposals concerning the revision of the German legislation are not likely to give an answer to the increasing $\mathrm{CO}_{2}$ emissions. One way out of the problems would be a stricter ETS (Emission Trading System) regime at the EU level. In its present form, with a too low price of less than 10 Euro/t for $\mathrm{CO}_{2}$ emissions under the present ETS, there are practically no incentives to switch over from fossil to renewable energy.

Moreover, a number of EU states like UK and the Netherlands, which exploit and export natural gas, have in financial respect no strong incentive to adopt nationally binding targets for renewables. This may explain a recent position [28] by Prime Minister Cameron where he, in response to dependence on Russian gas imports, refers not only to the possibility of imports from US and Iraq, but also for more European shale gas and nuclear energy. Poland, with presumably largest shale gas reserves in Europe, is another advocate of shale gas.

\section{Second dividing line: $\mathrm{CO}_{2}$ emission reduction target}

In 2012, with respect to $1990, \mathrm{GHG}$ emissions in the EU decreased by $18 \%$ - partly due to the economic restructuring in Eastern Europe and the economic crisis. Being presently responsible for $11 \%$ of the annual global emissions, a further reduction of $40 \%$ by 2030 would contribute only $4.5 \%$ to the global emissions in 1990 - and relatively even less in view of the worrying rapid increase of emissions world-wide. Conservative European politicians argue that since coping with global warming can be reached only through global action, Europe should not adopt ambitious targets as long as a global agreement has not been reached ("world would still be getting warmer, but Europe poorer"). Green and allied politicians, on the contrary, argue that Europe must show leadership by demonstrating that an ambitious climate policy can deliver green growth and employment, thus setting an example for the rest of the world. Within the EU, most states and the European Parliament supported the $40 \%$ reduction target. For countries like Denmark, Germany and The Netherlands, this was the minimum. Poland did not agree and finds support of most countries of Central and Eastern Europe. Finally, two arguments acted in favour of a $40 \%$ reduction target: (a) emission reduction of less than $40 \%$ would make a target of emission reduction by $80 \%$ or $95 \%$ in 2050 even less 
credible; and (b) reduced availability of Russian gas due to the crisis in the Ukraine, strengthened the advocates of a more rapid decarbonisation of economy.

The key elements of the 2030 Climate and Energy Policy Framework adopted by the EU Council on 23 October 2014 are as follows [19].

A binding greenhouse gas $40 \%$ reduction target below the 1990 level, to be met through domestic measures alone; the reductions in the ETS and non-ETS sectors shall amount to $43 \%$ and $30 \%$ by 2030 compared to 2005 , respectively.

A well-functioning, reformed Emission Trading System (ETS). The annual reduction in the 'cap' on emissions from EU Emission Trading System (ETS) sectors will be increased from $1.74 \%$ now to $2.2 \%$ after 2020 .

Renewables and energy efficiency. An EU-wide binding target of at least $27 \%$ is set for the share of renewable energy in 2030. It will not be translated into national targets through EU legislation, thus leaving flexibility for Member States to transform the energy system in a way that is adapted to national preferences and circumstances. The integration of rising levels of intermittent renewable energy requires a more interconnected internal energy market and appropriate back up. An indicative target at the EU level of at least $27 \%$ is set for improving energy efficiency in 2030. It will be delivered in a cost-effective manner and it will fully respect the effectiveness of the ETS-system in contributing to the overall climate goals. This will be reviewed by 2020, having in mind an EU level of 30\%.

Achieving a fully functioning and connected internal energy market is of fundamental importance and a matter of urgency. Preventing inadequate interconnections of Member States with the European gas and electricity networks and ensuring synchronous operation of Member States within the European Continental Networks as foreseen in the European Energy Security Strategy will also remain a priority after 2020.

Governance. The European Council agreed to develop a reliable and transparent governance system ensuring to meet energy policy goals facilitating coordination of national energy policies and fostering regional cooperation between Member States.

Energy security. The European Council endorsed further actions to reduce the EU's energy dependence and increase its energy security for both electricity and gas, and recognised that it can be increased by having recourse to low carbon technologies. It emphasised the importance of critical project in the gas sector, such as the NorthSouth Corridor, the Southern Gas Corridor, as well the need to ensure diversification of energy suppliers and routes, and market functioning. It also recalled its goal to build an Energy Union.

The issue of energy security will be addressed in more detail in subsequent chapters. 


\section{Current status of european energy policy and supply security}

\subsection{European energy policy in crisis}

The energy policy of the EU is based on three main pillars: sustainability (the climate component of it having been discussed in previous sections); security of energy supply; and competitiveness through market liberalisation. Due to present financial and economic pressures, all three pillars are full of uncertainties. Energy security is additionally threatened by the geopolitical factors and the lack of a coherent external energy policy. Market liberalisation and thus competitiveness are under pressure by protectionism. Environmental sustainability is put in question by related costs. The three challenges - competitiveness, sustainability and energy security - are mutually partially supporting, but partially contradicting. ongoing energy market reform will be crucial.

\subsection{Reform of the European energy market}

Even before the Ukraine crisis, the EU energy sector policy has been undergoing an evolutionary reform process. With reference to the fundamental principles of the EU (free movement of goods, capital, services, and people), the EC has been promoting market liberalisation as the basis for the efficiency of the energy sector and the competitivity of the economy as a whole. On the one hand, the energy sector must conform to the general principles of the free market, in particular to the general anti-monopoly laws such as those referring to free price formation and prohibition of price fixing by monopolistic interest groups. On the other hand, between 1996 and 2003, several directives and regulations aiming specifically at gas and electricity sectors were adopted, requiring that transmission grids be be managed independently from production and supply. These directives aim at thoroughly transforming gas and electricity industries from monopolistic conglomerates into competitive markets. Still in 2007, the Commission reported "serious problems" in the unbundling of gas and electricity markets, as the still vertically integrated companies dominated state or regional monopolies. Rapid ascent of decentralised electricity production from solar and wind was an additional reason for speeding up the reform of energy markets and corresponding infrastructures. The liberalisation of energy markets has emerged as key condition and factor in the process to make them mature for a larger contribution of renewables.

The correct transposition of the European electricity and gas legislation in all Member States is still not complete. Because of this, the Third Internal Energy Market Package was adopted in 2009 to accelerate investments in energy infrastructure to enhance cross border trade and access to diversified sources of energy. It consists of two directives and three regulations [29]. The three main options to weaken the market power of the biggest gas and electricity firms include: ownership unbundling; 
independent system operator (ISO); and independent transmission operator (ITO). Ownership unbundling is intended to split electricity generation from transmission, thus ensuring that the market does not suffer from vertical integration. Another possibility is to let the transmission networks remain under the ownership of energy groups, but transferring operation and control of day-to-day business to an independent operator. A third option, the ITO, envisages energy companies retaining ownership of the transmission networks, with transmission subsidiaries being legally independent joint stock companies, under a strictly autonomous management and under stringent regulatory control [29].

There have been dividing lines within the EU between the Commission, Parliament, the Member States and various interest groups with respect to several issues of energy sector liberalisation. France, and partly Germany, were against dismantling of big (national) energy companies; and there was no common will to reduce the generous allocations of industrial emissions under the ETS. Several gas supply crises (2006, 2009) led to the guidelines for trans-European energy infrastructure in 2013 [30]. On top of that, after numerous failed attempts to finalise bilateral energy co-operation agreements with Russia, the Commission has proposed a tough 'reciprocity clause' for energy relations with third countries. The move is widely seen to be targeted at Russian state-controlled energy giant Gazprom. The reciprocity clause was inserted as an apparent response to fears that ownership unbundling - the separation of integrated energy firms' production assets from their transmission assets - would lead to the indiscriminate acquisition of EU energy grids by third countries. "To protect the openness of our market, to protect the benefits that unbundling will bring, we need to place tough conditions on ownership of assets by non EU companies to make sure that we all play by the same rules," Commission President José Manuel Barroso said in a statement on 19 September 2007, the day the Commission unveiled its new proposals [31]. As will be seen, this "Gazprom clause" is playing a key role in the response of the EU to the Ukraine crisis.

Neither of above mentioned instruments was able to give a definitive and effective response to a number of significant challenges and developments within and beyond the borders of the EU. These include: (1) the continuously increasing import dependency of the EU (54\% of internal energy consumption of EU-27 in 2010 is based on imports; the dependency is increasing); (2) technological improvements of the main competitors (exploration and horizontal drilling in deep ocean, "fracking" technology for shale gas and oil); (3) new directions of energy supply (new gas and oil pipelines from Central Asia; cheaper gas in the USA, and thus cheaper coal from the USA; USA on the way to US energy import independence; plans for the exploration and drilling in the Arctic Ocean); (4) ascent of new energy producers: Africa, Latin America. All these challenges will remain unanswered unless the EU succeeds in adopting a common and coherent external energy policy. 


\subsection{Current European security of energy supply: the broad picture [32]}

Total demand for energy has been increasing slowly in the period 1995-2006, but since then has been gradually falling. It is now more than $8 \%$ below its 2006 peak due to a combination of factors (economic crisis, structural changes, efficiency improvements). The composition of gross inland consumption changed slowly, with the share of gas going up from around $20 \%$ to $23 \%$ between the mid-1990s and 2012, the share of renewables more than doubling to almost $11 \%$ in 2012. Shares of solid fuels declined from $21 \%$ to $17 \%$, oil from $37 \%$ to $34 \%$, whilst nuclear remained stable at $13 \%$.

Over a period of 20 years, import dependency has increased by almost a quarter due to decline of EU production of oil, gas and coal. However, since 2006, the increasing share of renewables as well as the reduction of overall demand contributed to a stabilisation of import dependency. Oil constitutes at almost $90 \%$ one of the largest shares of import dependency, followed by $66 \%$ for gas and $62 \%$ for coal. The lowest import dependency of $4 \%$ occurs for renewable energy. Nearly all Member States are heavily dependent as 18 of them import more than $50 \%$ of their energy. Poland and UK have gone from having an energy surplus to a significant deficit, Denmark has changed from deficit to slight surplus.

Crude oil: risks of supply disruption are mitigated by liquid global oil markets and regulated stocks, but high import dependency can lead to price shocks.

Gas: development of markets and gas infrastructure (interconnectors, reverse flows and storage) are improving resilience, but a short term winter supply disruption through Ukraine transit routes may pose significant challenges, in particular for Bulgaria, Romania, Hungary and Greece. The Baltic States, Finland, Slovakia and Bulgaria were until recently dependent on a single supplier - Russia's state-owned Gazprom - for their entire gas imports (Fig. 1).

The flexibility of transport infrastructure in terms of location, number and available capacity of pipelines and LNG terminals, underground storage and the way infrastructure is operated all play an important role in shaping the resilience of the gas sector. The potential to operate pipelines in two directions increases the resilience in case of supply disruption. Further investment in physical reverse flows is therefore important. EU import pipeline capacity is equivalent to $8776 \mathrm{GWh} /$ day, roughly comparable to the capacity of LNG terminals $(6170 \mathrm{GWh} /$ day $)$. The scope for using more of the LNG capacity depends largely on their location and infrastructure. There is more scope on the Iberian peninsula and less for supplies in Eastern Europe. The European Network Transmission System - Gas estimated that potential disruptions of piped Russian gas will affect a majority of EU member states directly, except for France, Spain and Portugal.

Solid fuels: increasing import dependence, liquid markets, but low level of modernisation, ageing coal power plants, low efficiency and lack of diversification lead to high carbon intensity in some countries. Between 1995 and 2012, the demand declined by almost $20 \%$, falling in nearly all Member States. The import dependency 
has been increasing also due to the closure of uncompetitive mines, and currently stands at $42 \%$.For hard coal, this figure increases to more than $60 \%$, with Russia being the main source.

Nuclear: supply of uranium is diversified, but final fuel assemblies are not, notably for Russian reactors in Bulgaria, Czech Republic, Finland, Hungary and Slovakia.

Renewable energy is the most indigenous resource with greatest fuel diversity, but with concerns regarding the variable nature of wind and solar power, creating challenges in terms of reliability, and requiring adaptation of the grid.

Electricity is an increasingly diverse fuel mix with high system reliability, but more integrated and smart infrastructure is needed to enhance market functioning, improve efficiency and the integration of renewable and distributed generation. The limited storage capabilities pose particular challenges to the transmission and distribution network infrastructure.

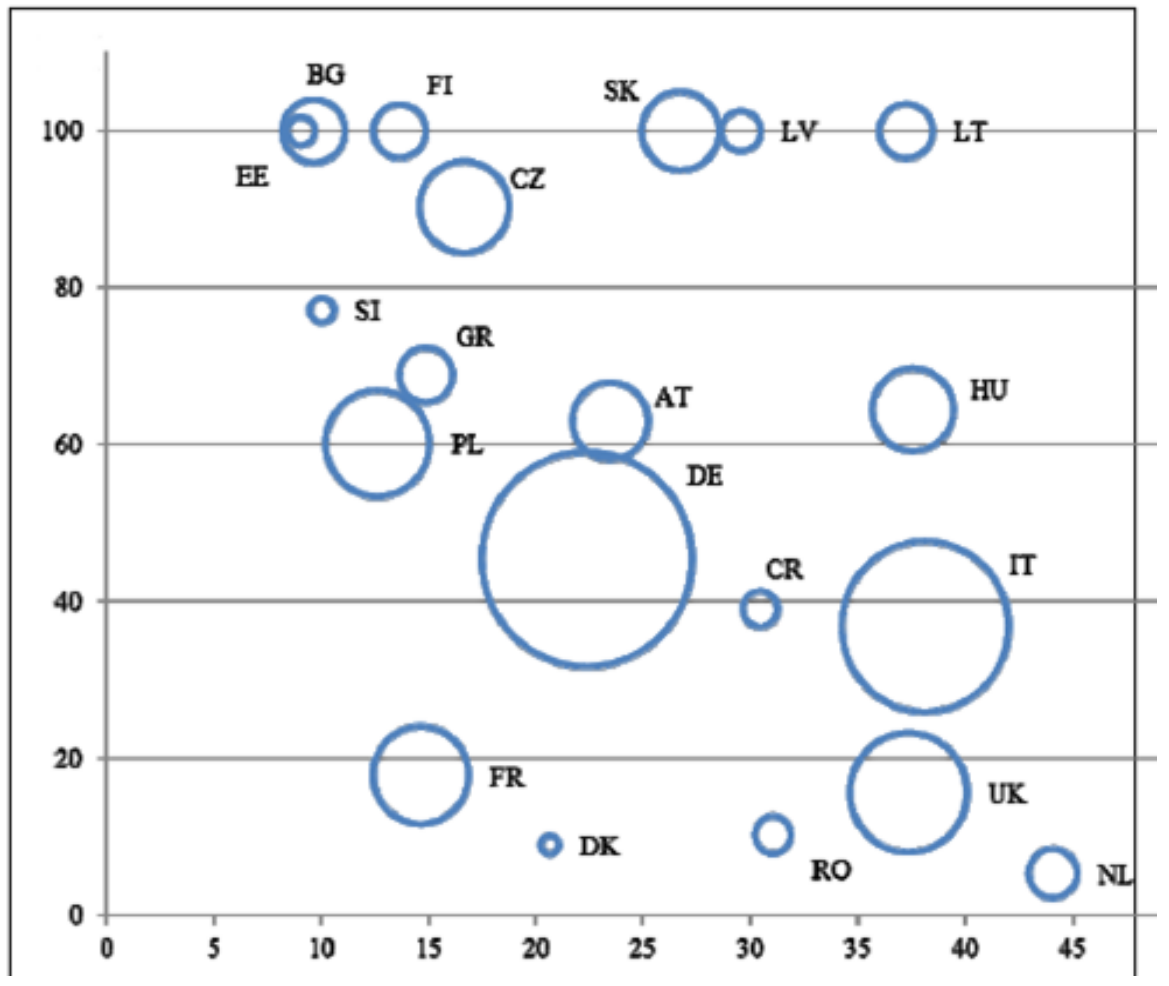

Fig. 1: Dependency of EU member states on natural gas supplies from Russia (2014). Horizontal axis: \% of natural gas in the energy mix; vertical axis: \% of Russian natural gas in national natural gas consumption; size of circles: volume of imported Russian natural gas. [33] 
Existing measures on energy capacity, transport and storage: for oil, following IEA practice, the EU has oil stock storage rules and demand restraint action plans that can help improve short term resilience in the event of a price or supply shock. In the gas sector, EU rules for responding to shocks are weaker. Recent EU infrastructure policy measures improved reverse gas flow options and reduced the weakness of resilience. Adequate inventories make a shortage of nuclear fuel highly unlikely.

The Commission "Policy framework for climate and energy in the period from 2020 to 2030" [18] [proposes to increase indigenous energy sources reduce energy consumption. The proposed governance scheme, based on national plans for competitive, secure and sustainable energy, should increase regional coordination and coherence between EU and national policies. Success indicators include: diversification of energy imports and increase of indigenous energy sources; deployment of smart grids and interconnections between Member States; and technological innovation. The projected reduction in total demand is important from an energy security perspective, but also from an economic perspective to reduce the total import bill.

\section{Energy in the post-cold-war confrontation}

\subsection{The Ukraine crisis}

As stated by Timothy Snyder, a historian and expert on Eastern Europe [34], the Russian invasion and occupation of the Ukrainian province Crimea was a frontal attack on the European security order and on the Ukrainian state. Putin's statement in 2005 that "disintegration of the Soviet Union represented the largest geopolitical catastrophe of the $20^{\text {th }}$ century" [35] implies two things: (a) underpinning of Russia's aim to regain lost territories and influence, e.g. through the emergence of the Eurasian Union; and (b) the high priority Russia's leadership assigns to geopolitical considerations. Ukraine has become a place of confrontation, with enormous consequences, between the "soft power" EU and Putin's "hard power" of old nationalistic type [36]. According to Bruno Tertrais of the Fondation pour la recherche strategique in Paris, as quoted by Bridel [37], "Putin makes the synthesis of Tsarism and Stalinism". The most probable Russian goal remains to keep Ukraine paralysed, and as such unsuitable for membership in both NATO and the EU [38]. In this confrontation, the whole spectrum of weapons - military, political, economic, and propagandistic - may be used.

What can be or will be a response of the West to Russia's confrontational course? According to the former German foreign affairs minister Joschka Fischer [39], the key to the Ukrainian crisis lies in the EU. Putin cannot be impressed by sanctions, but only by a power political (machtpolitisch) consensus within the EU, whereby a joint energy policy would be the first strong sign. The Ukraine crisis thus focused the attention upon the role of Gazprom in European natural gas supplies [40], the more so as oil and gas are, apart from being potential political and economic weapons, the dominant material export product of Russian Federation. 


\subsection{Energy/gas as weapons in the post-Cold-War confrontation}

The collapse of the Soviet Union and its satellite governments in Central and Eastern Europe opened up those economies to globalization and made their energyrelated natural resources available on global markets. Developed, yet energy-poor, Western economies saw opportunities to enhance their energy security through those economies. According to Leal-Arcas and Filis [41], the EU has sought to entangle those energy-rich states (or otherwise 'energy-significant', e.g., regarding energy transit) into multilateral regimes - such as those based on the Energy Charter Treaty $(\mathrm{ECT})^{2}$ and the Energy Community $(\mathrm{EnC})^{3}$. While both these special regimes count among their numbers several parties that are not EU member states, they are not neutral in their raison d'etre, given that these regimes were inherently linked to the energy interests of an increasing number of EU economies. The ECT was a timely response to significant geostrategic events - the collapse of the bureaucratic regimes in the eastern and central part of Europe and the re-shaping of machtpolitik regionally - that had enhanced opportunities for the industries of the developed Western EU member states to access energy resources in those regions, whilst the $\mathrm{EnC}$ came a few years later to place on a more institutionalized footing the integration of energy markets - chiefly gas and energy - through regulatory convergence across EnC members. In the case of the $\mathrm{EnC}$, the $\mathrm{EU}$ is afforded a prominent position in that certain areas of its acquis are inducted into the EnC's legal order, the $\mathrm{EU}$ has more influence than its $\mathrm{EnC}$ peers in the highest decision-making bodies of the $\mathrm{EnC}$, and the $\mathrm{EnC}$ is essentially the realization of EU external energy policy with those states between it and its main energy supplier, namely Russia [41].

In the last few years, however, EU has been confronted with a Russia using its energy exports as a political weapon against its poorer members that were previously under Soviet domination. Putin's Russia attempted "to play off wealthy Western Europe against poorer Eastern members by offering price flexibility to France and Germany while treating a Poland, a Bulgaria, or an Estonia as if they still fell under the Brezhnev Doctrine. That was the Soviet Union's notion of its immediate neighbours' limited sovereignty, reiterated by President Dmitri Medvedev after Russian troops entered Georgia in 2008" [42]. In response to that development the European Commission

$2 \quad$ The Energy Charter Treaty was signed in Lisbon in December 1994. For membership, see: http:// www.encharter.org/index.php?id $=61 \& \mathrm{~L}=1 \% 2 \mathrm{Ffileadmin} \% 2 \mathrm{Ftemplate} \% 2 \mathrm{Ftypo} 3$ conf $\% 2 \mathrm{Fext} \% 2$ Fdropdown_sitemap\%2Fpi1\%2Fplus.gif. The Russian Federation has signed ECT, but did not ratify it. It was applying it provisionally until 18 October 2009 inclusive.

3 The Energy Community was established by an international law treaty in 2005 in Athens, Greece. See: http://www.energy-community.org/portal/page/portal/ENC_HOME/ENERGY COMMUNITY/Who_are_we. The Parties to the Treaty are presently (status 1 Jul 2013): European Union and eight Contracting Parties, comprising Albania, Bosnia and Herzegovina, Kosovo*, fyR of Macedonia, Moldova, Montenegro, Serbia and Ukraine. Armenia, Georgia, Norway and Turkey take part as Observers. Georgia is presently in the process of joining the Energy Community as a full fledged member. 
opened formal proceedings against Gazprom on 31 August 2012, which resulted in April 2015 in a Statement of Objections to Gazprom alleging that some of its business practices in Central and Eastern European gas markets constitute an abuse of its dominant market position in breach of EU antitrust rules [43]. Gazprom is allegedly hindering competition in the gas supply markets in eight Member States (Bulgaria, the Czech Republic, Estonia, Hungary, Latvia, Lithuania, Poland and Slovakia) by implementing an overall abusive strategy in these gas markets, in particular through: territorial restrictions; unfair pricing policy; and by making gas supplies conditional on obtaining unrelated commitments from wholesalers concerning gas transport infrastructure. Lithuania claimed almost $€ 1.3$ billion compensation from the company at an international arbitration in Stockholm for allegedly "unfair" gas prices [44].

Russia's strategic attitudes and means when using energy/gas as economic and political weapon in the ongoing post-Cold-War confrontation may be characterised as follows.

a. Assigning high priority to the extension of territorial control (e.g. by territorial claims in the Arctic ; by controlling energy supply to, and through former Soviet republics and former Soviet satellite states; the importance of Crimea for controlling presumed Black Sea gas/oil fields); this in contrast to lower priority, or systemic inability, for innovation (backlog in deep ocean oil/gas exploration and drilling; backlog in fracking technology; negligible investments in renewable solar/wind energy).

b. Striving to cement Gazprom dominance in the EU gas market [45]. On that account, trying to bypass, or even discipline by retortion measures, possible troublemakers (former Soviet republics like Baltics, Belarus, Ukraine, or former Central Europe satellite states like Czech Republic, Poland, Slovakia) ${ }^{4}$; at the same time relying upon willing countries like Greece, Hungary, Serbia; and in case of serious resistance, as in Ukraine, military intervention not being excluded.

c. Increasing foothold in Germany, and Austria, both with excellent record for long-term energy contracts with Russia, by strengthening their roles as transit countries for other EU member states [48]. In 2006, President Vladimir Putin had publicly offered to select Germany as a distribution hub for Russian gas in Western Europe [49]. This implies extension and vertical "bundling" of gas infrastructures owned by Gazprom, including ownership of pipelines from Russia to Germany and Austria, of critical gas storage on EU territory, as well of pipelines connecting Germany, and possibly Austria, to other EU member states, if needed by breaching EU law.

d. Making use of the weaknesses of the EU, such as: lack of a common and coherent EU external energy policy; high dependency of some EU member

$4 \quad$ A Swedish Defence Research Agency study counted over 55 incidents 1991 and 2007, most with "both political and economic underpinnings" [46], [47]. 
states on gas imports from Russia; poor or inconsistent implementation of relevant anti-monopoly and "unbundling" EU legislation, even within the EU member states. With the backing of the Kremlin, and sometimes help from interested European parties, state-controlled Gazprom may be intent on rolling back stipulations of the Third Energy Legislation Package on EU territory [49].

e. Bringing if needed legal conflicts with the EU (anti-monopoly, unbundling) for litigation to the World Trade Organisation (WTO) or other arbitration forums.

Cases illustrating the above contentions are among others: the history and ongoing evolution of the Nord Stream Pipeline; the failed South Stream Pipeline, and its alternatives; and the associated political and legal controversies. As a common denominator, Moscow awards lucrative production and service contracts to major European companies to execute Gazprom's pipeline projects in Europe. Such contracts help generate political support within the EU for Gazprom's projects, sometimes irrespective of the EU's energy legislation.

\subsection{Nord Stream}

Nord Stream gas pipeline is an offshore natural gas pipeline from Vyborg (Russian Federation) to Greifswald (Germany), promoted by Russia's government and agreed by German government ${ }^{5}$. It also received support, in 2008 , by the European energy commissioner [51]. In its broader meaning, it includes the feeding onshore pipeline in Russia, and further connections in Western Europe (Fig. 2). It consists of two lines, inaugurated in

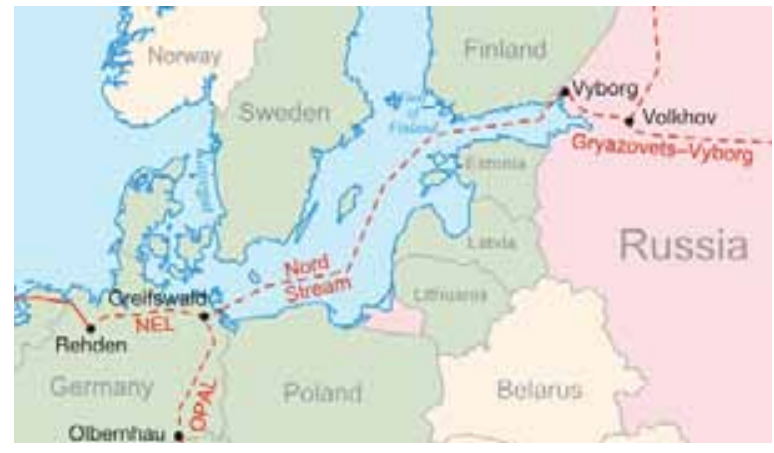

Fig. 2: Nord Stream with extensions [52]

$5 \quad$ The agreement to build the pipeline was signed ten days before the German parliamentary election in 2005. Soon after leaving the post of German Federal Chancellor, Gerhard Schröder agreed to head the shareholders' committee of Nord Stream AG. This has been widely described by German and international media as a conflict of interest [50] 
2011 and 2012, respectively. Its owner, Nord Stream AG, applied in 2012 to Finnish and Estonian governments for route studies in their exclusive economic zones for the third and fourth lines. Nord Stream feeds into OPAL in Germany, which in turn feeds into the Gazelle pipeline in the Czech Republic. OPAL and Gazelle, both being sourced from Nord Stream, connect to the existing pipeline grid in Middle and Western Europe, and open a new route for Gazprom into EU territory ${ }^{6}$. Nord Stream, 51 percent Gazprom-owned, is the largest-capacity offshore pipeline in Europe at 55 billion cubic meters (bcm) annually. OPAL and Gazelle, at $35 \mathrm{bcm}$ and $30 \mathrm{bcm}$ per year, respectively, are the largest-capacity onshore pipelines in EU territory [53]. Gazprom controls OPAL in Germany through the Gazprom-Wintershall joint company Gascade Gastransport, holding 80-percent ownership and operating rights.

The Nord Stream project was seen as highly controversial for various reasons, including increasing European dependence on Russia, bypassing of Poland, and potential environmental damage. Whereas Russia's position is that the pipeline increases Europe's energy security, as it would reduce Russia's dependence on the transit countries, some transit countries were concerned that the Kremlin may attempt to exert political influence on them by threatening their gas supply without affecting supplies to Western Europe [54]. By adding a third and possibly a fourth line to the existing two, Gazprom via Nord Stream would become the exclusive provider of Russian gas to OPAL and NEL [48]. These large-capacity lines are mainly intended to provide transit service for Russian gas across Germany, en route to third countries, mainly targeting gas markets in the EU beyond Germany. Targeted acquisitions of German storage capacities by Gazprom corroborate that intention ${ }^{7}$. The emerging transit system is so configured that OPAL and NEL can only be sourced with gas from Nord Stream. This would preclude an independent third-party's access to OPAL and NEL, except on terms amenable to the Russian side.

In Germany, as well as in Brussels, the Russian government was pressing for the OPAL gas pipeline to be released from the stipulations of the Third Legislative Package. Under the Third Legislative Package, a gas producer company supplying a given market may neither own and operate, nor exclusively use, pipelines and storage in that same market. A company in that position, such as the vertically integrated Gazprom,

$6 \quad$ Nord Stream also feeds into two other pipelines in Germany, NEL (towards Hamburg) and NORDAL (towards Berlin, still under planning).

7 With Nord Stream, OPAL and NEL controlled by Gazprom as the main shareholder, Germany gains a new significance as transit country, as well as a prime customer country for Russian gas. But Gazprom is also accumulating gas storage capacities, indispensable to supporting its export and transit operations in Germany. Development of storage capacities had lagged behind pipeline construction in Gazprom's export strategy in recent years. Nord Stream was built unaccompanied by gas storage sites, whether on Russian or on German territory. However, Gazprom and affiliated Russian firms have moved to develop underground gas storage capacities on German territory. Storage sites controlled by Gazprom in Germany are planned to operate in correlation with Gazprom-controlled transmission pipelines. This ongoing process of vertical bundling adds a long-missing dimension to Gazprom's export strategy in Europe [55]. 
is required to separate ("unbundle") its supply business from effective control of the infrastructure it uses. It is also required to allow competitor suppliers to use upwards of 50 percent of those pipelines' capacities ("third-party access"). The Third Package applies irrespective of whether the vertically integrated company in question has already made investments into the construction of those pipelines, or proposes to start doing so. But the European Commission has allowed Gazprom to take over WINGAS and to maintain pre-existing Gazprom-Wintershall joint control of German pipelines.

In February 2009, the Germany's energy regulator exempted the OPAL pipeline from network access and transit fees regulation for 22 years after its launch [56]. However, the exemption from competition regulations may breach EU regulations, and it was reported that the EU are investigating [57]. Gazprom applied for an increased access to the OPAL pipeline. Shortly before military intervention in the Ukraine, Russian President Vladimir Putin, concluding the EU-Russia summit in Brussels on January 28, 2014, hinted that European authorities would allow Gazprom to use as much as 100 percent of the OPAL pipeline's capacity. However, in July 2014, the European Commission and the German grid regulator Bundesnetzagentur agreed to postpone the deadline for a decision on OPAL [58].

A new chapter in the game concerning the expansion of the Nord Stream pipeline was opened in early September 2015 when Gazprom and its European partners (E.ON, ASF/Wintershall, OMV, ENGIE and Royal Dutch Shell) signed a shareholders' agreement on the Nord Stream-2 gas pipeline project (doubling the present transport capacity) that would bypass Ukraine and bring Europe closer into Moscow's energy orbit. Slovak Prime Minister Robert Fico said on 10 September 2015 that the deal was a "betrayal" that would cost Ukraine and Slovakia a combined billions of Euros [59]. Slovakia's and Poland's presidents, Andrej Kiska and Andrzej Duda, announced on 2 October 2015 that they are against the construction of Nord Stream 2 [60].

\subsection{Southern approaches}

The meekness and inconsistence in handling the rules of the Third Legislative Package with respect to Nord Stream may be explained by the faits accomplis, economically and politically in line with Germany's energy policy and the GermanRussian relations. But in the case of agreements signed with Moscow by smaller member countries to build South Stream, the European Commission chose to assume a more astute position.

South Stream was planned as a pipeline to transport Russian natural gas through the Black Sea to Bulgaria and through Serbia, Hungary and Slovenia further to Austria, with links to Croatia and Macedonia. The Russian government and Gazprom have signed between 2008 and 2013 inter-governmental and corporate agreements to build sections of the South Stream pipeline system in six willing EU member countries (Bulgaria, Hungary, Austria, Slovenia, Croatia, Greece), as well as in Serbia, Macedonia and through Turkish territorial waters. The joint venture South Stream AG, equally 
owned by Gazprom and ENI, was registered in 2008 in Switzerland, and a shareholders' agreement, signed between Gazprom, ENI, EdF and Wintershall established a new company South Stream Transport AG. Construction of the Russian onshore facilities for the pipeline started in December 2012 [61].

The project has created controversies, including due to non-compliance with the EU competition and energy legislation. South Stream has been seen as diverting some gas transported through Ukraine, instead of providing a new source of gas for Europe [62]. It was seen as rival to the now abandoned Nabucco pipeline project. The EU has frequently advised Russia and its European partners that agreements on the construction of the South Stream pipeline should comply with the EU's Third Energy Package regulations. As expected, three main issues have raised particular concern in Brussels [63]. First, network ownership "unbundling" requires the separation of energy supply and energy network provision. Gazprom had 50-51 percent ownership of the joint companies that were supposed to construct and own the pipeline. Second, Gazprom was not willing to allow non-discriminatory access of third parties to the pipeline. Third, an independent operator, instead of the pipeline owner(s), should have determined the transit tariffs. Energy Commissioner Günther Oettinger said in December 2013 that the bilateral agreements signed by seven countries with Moscow must respect EU law [64].

While Washington and Brussels were imposing more sanctions against Russia for destabilizing eastern Ukraine, the Kremlin was retaliating by deepening divisions within the European Union through the prospective South Stream natural gas pipeline [65]. On April 17, 2014 the European Parliament adopted a resolution stating that the South Stream pipeline should not be built and the EU should look for other sources of supply to reduce dependence on Russian gas [66]. However, several European countries including Hungary, Italy and Austria were still trying to salvage the project, claiming that it is strategically important for Europe. Remarkably, Austria's Economy Minister Reinhold Mitterlehner expressed support for the efforts of the parties on the implementation of the South Stream project on Austrian territory [67]. Another supporter of South Stream appeared to be Bulgaria, which is heavily dependent on Russian energy and seems to have extensive non-transparent ties with Russian energy corporations. The disagreement on the South-Stream Project led to a split within the government coalition [68]. Eventually, Bulgaria suspended South Stream in June 2014 after the Commission started an infringement procedure against Sofia [69]. Serbia, the other staunch backer of South Stream, has failed to respond to repeated requests from Brussels to inspect the operations of Srbijagas and Yugorosgas, the transmission system operators in the South Stream section through Serbia. As a result, the EU Energy Community has asked the EU Council to examine the legality of bilateral agreements on the construction of the South Stream gas pipeline concluded between Serbia and Gazprom. The European Energy Community considered the agreements between Serbia and Gazprom as not in compliance with EU rules on competition [70]. The new Serbian first deputy prime minister and minister for foreign affairs Ivica Dačić has stated in April 2014 that his country "would never join any sanctions against Russia, because 
for us Russia is not just a friendly country, an economic and political partner, but also a country that has never imposed sanctions against Serbia" [71]. However, in October 2014, Serbia announced it may have to suspend construction of the South Stream gas pipeline through its territory, after Bulgaria said it was halting work on its segment of the pipeline [72].

Russia has initially decided to take the dispute to the World Trade Organization (WTO), claiming that the South Stream project is international and that EU rules should not be applicable to it. "The Third Energy Package, in the opinion of Russia, contradicts the obligations of the EU in [the] WTO on basic principles of non-discrimination and market access," said a spokesman of Russia's economic development ministry [65]. But on December 1, 2014, President Putin announced that the proposed South Stream pipeline will not go ahead [73].

The demise of the South Stream led to a number of developments and speculations concerning the supply of gas to Southern and South- Eastern Europe. Italy is increasingly looking to the development of the Southern Gas Corridor (SGC), which would link gas fields in Azerbaijan to the Italian/Adriatic region via Georgia, Turkey, Greece and Albania. The SGC is expected to connect three separate conduits: the existing South Caucasus Pipeline $\left(\mathrm{SCP}^{8}\right)$ and the planned Trans-Anatolia Natural Gas Pipeline $\left(\right.$ TANAP $\left.^{9}\right)$ and Trans-Adriatic Pipeline $\left(\mathrm{TAP}^{10}\right)$. The consortium of nations involved in the SGC project is also keen to extend the energy corridor eastward to natural gas producer Turkmenistan through a proposed Trans-Caspian gas pipeline [74]. However, Russia and Turkey agreed that Turkey's energy imports from Russia via the Blue Stream gas pipeline would increase from 16 to 19 billion cubic meters per year. The agreement has the potential of increasing Turkey's role as an energy hub in Europe, and ignited a debate among energy experts as to whether the proposed Turkish Stream ${ }^{11}$ pipeline would undermine hopes of one day constructing a Trans-Caspian pipeline between Turkmenistan and Azerbaijan [75]. Aleksei Miller, the CEO of Gazprom, wrote in January 2015 that Russia intends to stop all shipments of gas to Europe via Ukraine as soon as it completes a new pipeline corridor via Turkey. In a geopolitical analysis [76], several goals of the Kremlin were seen as motivation behind Miller's warning: (a) easing EU sanctions; (b) blackmailing the EU to give Gazprom free hand; (c) destroy any hope of Ukraine's self rule; (d) prevent other former Soviet republics from pursuing European integration; (e) establish Turkish dependence on Russia as the major provider of gas; (f) place pressure on Turkey to downgrade the TANAP-TAP line and prevent Caspian-area producers to connect directly to European markets.

8 SCP gas pipeline connects the Shah Deniz gas field in the Azerbaijan sector of the Caspian Sea to Turkey. It runs parallel to the Baku-Tbilisi-Ceyhan oil pipeline.

9 TANAP will run across Turkey from the border with Azerbaijan to the border with Greece.

10 TAP will start from Greece via Albania and the Adriatic Sea to Italy and further to Western Europe.

11 Turkish Stream pipeline to run across the Black Sea from Russkaya CS near Anapa in Russia to Kiyikoy village in the European part of Turkey, partly along the old corridor of South Stream. 


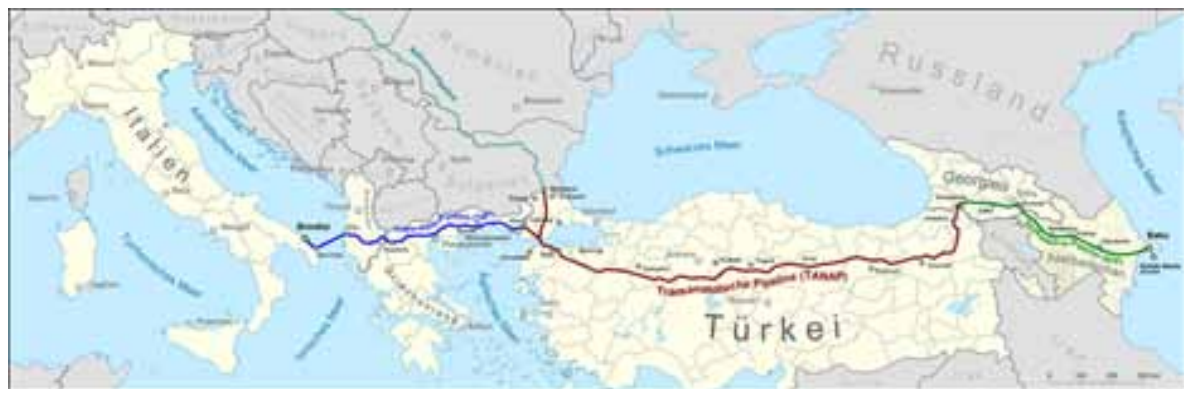

Fig. 3: Southern Gas Corridor [77]

Russia's geopolitical game has been hitting upon several obstacles. A particularly important one was the Statement of Objections by the European Commission of April 22 2015 , mentioned earlier. But there are several others, reflecting the growing impatience with Russia's way of using gas export as a political weapon.

(a) Ukraine's negotiating position improving. Lately Ukraine has been successfully reducing its dependence on gas imports from Russia. Far-reaching changes on the energy markets in Europe and Ukraine are increasingly neutralizing Russia's ability to pressure Ukraine and Europe through manipulation of gas supplies and transit. Thanks to EU market liberalization and Central Europe interconnections, European energy companies are themselves gaining market share by reselling gas of Russian and other origins in growing volumes to Ukraine. Ongoing expansion of reverse-flow pipeline capacities, particularly through Slovakia, makes this possible, particularly through the construction of the Slovakian-Ukrainian pipeline interconnector, Vojany-Uzhhorod, and the expansion of its capacity. Gazprom's sales to Ukraine have declined both in market share and in quantitative terms. Gazprom's discounted price at USD 248 seems designed to outbid Europan competitors. [78]

(b) China business seems more uncertain that thought before [79]. Moscow has struggled for nine years to finalize plans for gas exports to China. Despite handshakes and high-profile events, signs point to continued tensions in Russia-China energy ties. In 2006, President Putin agreed to build two gas pipelines to China, one from the east and one from the west, but the two countries have been at odds ever since over which should be given priority. Russia has always preferred the western route from its existing Siberian gas fields through its Altai region to Xinjiang, which would be shorter and cheaper for Gazprom than the eastern line to China's northeast industrial region and coastal cities from yet undeveloped resources in East Siberia. Moscow's pressure on Beijing to prioritize the western gas pipeline to China over the eastern route only raised doubts about Russia's commitment to the first gas pipeline that it had promised to complete by end-2018. However, the contract for the eastern route had never been finalized, since the terms were contingent on an intergovernmental agreement that Russia had yet to ratify. But conditions have changed dramatically since last year when the contract for the eastern route was signed with an estimated value of $\$ 400$ billion and 
a presumed starting price of $\$ 350$ per thousand cubic meters ( $\mathrm{mcm}$ ). Russia's strategy of insisting on equal netbacks appears to have backfired, due in part to its attempts to isolate Ukraine. In September 2014, Russia limited gas supplies to European customers by restricting them to contract minimums in order to discourage "reverse flow" sales to Ukraine. The developments left China wondering why it should be stuck with a starting price of $\$ 350 / \mathrm{mcm}$, when Gazprom is now selling gas to Ukraine at $\$ 247 / \mathrm{mcm}$. There is still no agreement on the commercial price for the western route. Gazprom CEO Alexei Miller has continued to warn Europe that "gas could go to other markets." In mid-April, Miller told a Berlin conference that "the Asian market will be a factor in pricing for the European market" over the next decade. This seems to be an empty bluff since Gazprom's complex negotiations with China, together with expensive pipeline construction and complex new-field development, will delay significant gas flows beyond 2020 .

(c) Future role of Turkey. Turkey is signed on to the Southern Gas Corridor, but it is also being strongly courted by Moscow to host Turkish Stream. Turkey's central role within the South Gas Corridor and its potential relations with or even inclusion in an EU Energy Union structure is threatening to Russia's continued dominant position in the region Moscow considers its "near abroad."[80] Not only is Russian trying to split Greece from the rest of its EU partners, but Turkish Stream is also designed to skirt EU supervision since the planned pipeline will be open to Europe only at the border with Turkey, where Europe's energy legislation does not extend. According to an US analyst [81], Turkish Stream probably will not be built because it makes little economic sense and its costs are almost certainly underestimated. TANAP and Turkish Stream will compete in the future to pipe gas toward Europe, according to Kenan Yavuz, the Turkey CEO of the State Oil Company of Azerbaijan (SOCAR). Europe does not need additional flows of natural gas at the moment: its current consumption is estimated at some $357 \mathrm{bcm}$ - the same level as in 1995, and well below its peak of 2007-2010. Therefore, the fate of Turkish Stream and TANAP will ultimately be determined by geopolitical factors. According to Yavuz, "TANAP is the only project that brings not only route but also supply diversity for European end-users". [82].

\section{Challenges to EU energy-gas security: disruption scenarios and responses}

\subsection{Disruption risks of Russian gas natural gas supply to Europe}

Civil unrest in Ukraine, disputes with Gazprom over natural gas prices and transit fees have led to the fear of an interrupted natural gas supply to Ukraine and via Ukrainian transit pipelines to the EU. In the spring of 2014 the situation seemed more severe comparable to 2006 and 2009, but since 2009 both the global and the European natural gas sectors have significantly changed in various ways [83]. (a) Since the inauguration of the Nord Stream pipeline in the late 2011, Russian exports via the 
Ukraine have diminished from $65 \%$ to $50 \%$ of all Russian exports to Europe. (b) EU28 countries have reduced the share of Russian gas imports from in total 50\% in 2001 to $37 \%$ in 2012. (c) The EU regulation 994/2010 harmonised national emergency plans and led to expansion of EU interconnectors allowing for reverse flows. (d) The import capacity of LNG in the EU has been expanded by $15 \%$ between 2009 and 2014. LNG imports could still be increased since utilization rates are low with only $30 \%$ on average in the EU in 2012. (e) While US natural gas imports have been more than $50 \%$ lower in 2013 than in 2009 , production has increased by almost $20 \%$ due to a boom in shale gas extraction. Some projections expect the USA to become a net exporter of natural gas as of 2020. (f) In 2012, natural gas consumption in the EU has been lower by $4 \%$ than in 2009. This was due to the economic crisis and low $\mathrm{CO}^{2}$ prices.

The EU seems to be better prepared for any disruption of Russian supply, with Russia being dependent on its main customer. Asian market is an alternative, but in the short run actual trade flows are limited due to a lack of production and transportation infrastructure.

Despite all progress, the disruption of Russian natural gas exports to Europe may have severe consequences, in particular for several Eastern European countries. Richter and Holz [83] investigated in May 2014 the European natural gas market position, focusing on alternative gas suppliers, and analysing the expansion of existing infrastructure. Their results indicate that the EU LNG import capacity is insufficiently connected to the broader market. Particularly, cross-border pipeline capacity restrictions prevent higher Spanish LNG imports used for an efficient distribution across Europe. Similarly, Italy is poorly connected to central Europe and cannot serve as transit country for African pipeline gas and LNG imports. Hence the large total EU regasification capacity of $195 \mathrm{bcm}$ cannot be completely used to balance import needs in all member states.

The Russian-Ukrainian crisis of 2014 has revitalized the European concerns of supply disruptions of natural gas as experienced in 2006 and 2009. Despite being better prepared today, several East European countries are highly dependent on Russian natural gas. LNG imports play a vital role in replacing Russian gas, although a large part of the European LNG import capacity is not well connected to the broad market. In case of a long lasting interruption of Russian supply, more investments in the intraEuropean transportation infrastructure are necessary to diversify the EU imports and balance the internal market ${ }^{12}$. These include the connection of the Iberian peninsula and

$12 \quad$ Two examples may illustrate this point. Immediately after coming into power in 2010, the Orbán government advocated a gas pipeline connecting Hungary and Slovakia, which was accomplished on 27 March 2013 thanks to a subsidy by the EU [84]. Republic of Moldova, having an association agreement with the EU since 2 July 2014, is fully dependent on Russian gas, which comes through Ukraine and separatist territory of Transnistria. In a tour de force act, Moldova is now being connected with the Romanian gas pipeline system. The connection between the border city of Ungheni with the Romanian Iasi is to be officially opened end of August 2014. Its annual capacity of $1 \mathrm{bcm}$ corresponds roughly to Moldova's annual consumption of gas [85]. 
Italy to Central Europe to distribute the large import potentials of both countries from North Africa and the global LNG market. Pipeline expansions to reach the Baltics and Finland from Poland are advisable, as well as investments in the Southern Corridor to bring gas from the Caspian region and the Middle East via Turkey to those countries, which are most affected by a Russian supply disruption.

\subsection{EU's possible responses to energy security challenges}

Even though conventional concerns about European energy security focus primarily on the external dimension of the issue, namely on diversification of sources, routes and suppliers, the supply security of the EU encompasses an internal dimension too, which refers to the necessary domestic infrastructure that each member state has in place for production, transport and consumption of energy. This internal dimension can be further broken down into two aspects: the management of energy demand and the promotion of energy independence [86]. The first issue refers to increased energy efficiency and energy savings - topics addressed earlier in the present paper. The second aspect of the internal dimension of EU energy security policy refers to self-sufficiency, which includes domestic production of energy, modernization of energy networks and grids, and emergency response policies. The maintenance and modernization of the energy network is carried out through infrastructure investments, such as the Baltic Energy Market Interconnection Plan (BEMIP). It was established in 2009 with the objective of connecting the remaining isolated energy markets in Europe through the identification of the missing necessary infrastructure and the financing required to its realization. BEMIP includes two electricity interconnections between the region and the Scandinavian Peninsula, the promotion of a Lithuanian nuclear power plant project, and the development of regional gas pipelines from Poland, Germany, Denmark and Sweden. The present author can partly agree with the conclusion of Piccolo [86] that "the internal dimension of the European energy security policy looks as a very promising tool to reduce the import dependency of member countries." But much has to be done still to stop risky gas dependency on Russian gas.

The European Commission proposed an energy security strategy in May 2014 [33]. The Strategy builds on a number of present strengths (e.g. 50\% of the EU electricity is produced without GHG emissions), and lessons learnt in the winters of 2006 and 2009 when temporary disruptions of gas supplies strongly hit citizens in some of the eastern Member States), and sets out areas where decisions need to be taken or concrete actions implemented in the short, medium and longer term to respond to energy security concerns.

To ensure uninterrupted supplies during the winter 2014/2015, the Commission proposed to intensify cooperation within the Gas Coordination Group, continue monitoring gas flows and gas storage, and coordinate at regional or EU level risk assessments and contingency plans . The aim is to check how the energy system can 
cope with security of supply risks, and subsequently develop emergency plans and create back-up mechanisms. Such mechanisms could include increasing gas stocks, decreasing gas demand via fuel-switching (in particular for heating), developing emergency infrastructure e.g. through reverse flow possibilities and pooling parts of the existing energy security stocks. To address the medium- and long-term security of supply challenges, the Commission proposed actions in several key areas:

- Completing the internal energy market and building missing infrastructure links is essential to quickly respond to possible supply disruptions by directing energy flows across the EU as and where needed. The development of competitive and well integrated markets in the Baltic States and in the South East Europe still lags behind. Targeted approaches that speed up the development of critical infrastructure as well as the establishment of regional gas hubs in these regions are needed. In addition, antitrust and merger control rules must continue to be vigorously enforced since they ensure that EU security of supply is not weakened through anticompetitive behaviour or by anticompetitive consolidation on vertical integration of energy companies.The Commission has identified 33 infrastructure projects which are critical for the EU's energy security. Apart from that, the Commission proposes to extend the current 10\% target as regards interconnection of installed electricity capacity to $15 \%$ by 2030 while taking into account the cost aspects and the potential of commercial exchanges in the relevant regions.

- Diversifying supplier countries and routes. In 2013, 39\% of EU gas imports by volume came from Russia, 33\% from Norway and 22\% from North Africa (Algeria, Libya). While the EU will maintain its relationship with reliable partners, it will seek ties to new partner countries and supply routes, e.g. in the Caspian Basin region by further expanding the Southern Gas Corridor; by developing the Mediterranean Gas Hub and by increasing LNG supplies. Russia is a key competitor in nuclear fuel production, and offers integrated packages for investments in the whole nuclear chain. Particular attention should be paid to investments in new nuclear power plants to be built in the EU using non-EU technology, to ensure that these plants are not dependent only on Russia for the supply of nuclear fuel.

- Strengthening emergency and solidarity mechanisms and protecting critical infrastructure. In this respect the Commission will for example review the provisions and implementation of the Security of Gas Supply Regulation. Respect of existing EU legislation has to be guaranteed for any acquisition by non-EU buyers of strategic infrastructure, such as gas storage. The existing provisions on unbundling of gas transmission activities already foresee a mechanism to ensure that transmission system operators controlled by non-EU entities comply with the same obligations as those controlled by EU entities. The recent experience of certain non-EU operators seeking to 
avoid compliance with EU legislation on EU territory migh require a stricter application and a possible reinforcement of the applicable rules at EU and Member State level.

- Increasing indigenous energy production includes further deployment of renewables in conformity with climate policy targets; initiation of the Europeanization of renewable energy support systems through improved coordination of national support schemes; accelerating fuel switch in the heating sector to renewable heating technologies;and sustainable production of fossil fuels.

- Improving coordination of national energy policies and speaking with one voice in external energy policy. The Commission aims to be involved at an early stage in envisaged intergovernmental agreements with third countries that could have a possible impact on security of supply. Moreover, the Commission will ensure that all such agreements and all infrastructure projects on EU territory fully comply with the relevant EU legislation. The Commission welcomes the calls made by certain Member States in favour of an Energy Union.

- Further developing energy technologies.

- Increasing energy efficiency. As buildings are responsible for $40 \%$ of our energy consumption and a third of natural gas use, this sector plays a crucial role, not only for energy security but possibly even more so for climate change mitigation.

It is remarkable, however, that in contrast to the climate 2030 package, the Commission does not formulate quantitative goals with regard to the reduction of energy import dependence.

The proposal by the Commission was discussed, in October 2014, by the European Council, which adopted the 2030 Climate and Energy Policy Framework, however with only a short chapter on Energy Security. The Committee on Industry, Research and Energy of the European Parliament prepared in December 2014 a draft report (Rapporteur: Algirdas Saudargas) consistent with the Commission proposal [87]. However, the report failed to secure parliament's support [88].

The creation of an EU Energy Union in analogy to Euratom, was proposed by Donald Tusk when he was still Poland's Prime Minister, in order to end Russia's energy stranglehold [89]. Whereas the bloc's 28 members jointly buy uranium for their nuclear power plants through the EU's atomic energy agency, Euratom, they should take the same approach with Russia's gas. Whether in coal, steel, uranium, credit or gas, the principal idea of the EU has always been to bring Europe together, deepening security and establishing fair rules where the free market is lacking. As a follow-up, on 25 February 2015, the European Commission set out its strategy to achieve a resilient Energy Union, implying: a solidarity clause; energy flows, as if it were a Fifth freedom; energy efficiency first; transition to a low-carbon society that is built to last [90]. 


\section{Conclusions and outlook}

Climate change and energy security policies are intimately related. The respective approaches are very different among the major world players. The USA, still the economic and military world leader, and originally a cradle of the environmental movement, is betting on a bottom-up approach. With free market forces encouraging innovation and deployment of new technologies, not only in shale oil/gas, but also in solar and wind power [91], the USA have become independent of energy imports; their climate policy is still less impressive. The decision-making within the EU, depending on consensus among member states, has defined quantitative decarbonisation goals (but nothing similar on reducing dangerous energy import dependence), whereby implementation depends largely on national policies. Taught by the lessons of two world wars, the EU sees itself as a value-based "soft power", relying on the pan-European security and peace architecture that came into existence after the Cold War. Its member states, all united by adherence to democratic principles, are militarily in majority under the NATO umbrella, some are neutral, whereby both climate and energy policies are characterised by important dividing lines, which weaken the possibilities of long-term planning. Russia's economy, still strongly state-controlled, and based nearly exclusively on (export of) fossil energy resources, pays only lip service to climate change issues, and does not develop renewables. Seeing itself as a loser of the Cold War, authoritarian Russia continues to rely on the tradition of territorial expansion and control, neglecting innovation-based energy and environment related policies. The three powers are of course challenged by the rising super-power China. China's insistence on common but differentiated responsibilities with regard to climate change reflects its wish to be seen as responsible global player, but at the same time its determination to develop, as priority, its technological, economic, political and military potential until it becomes equal to any other super-power. A recent Chinese source claims already China's solar world dominance [92]. This development, as well as rising popular discontent about environmental deterioration, contributed to China's recent constructive moves with regard to mitigation efforts.

Soft-power EU will be confronted with tough, geopolitically conscious negotiators during the upcoming 2015 Paris climate summit. At the same time, it is facing serious energy security challenges. The EU, in its initial triumphalism after the end of the Cold War, lost its prudent approach by allowing to become increasingly dependent on energy imports from (potentially) unstable and/or unreliable regions. An unpredictable Russia, weakened by sanctions and low oil/gas price, has increasing problems in using its gas and oil as economic and political weapons. The simultaneously increasing political instability of some other importers EU depends upon (Middle East) contributes to the future energy security risks. The EU institutions have been slow, and sometimes inconsistent and divided on the use of existing powerful instruments - anti-monopoly and "unbundling" legislation - vis-á-vis Russian attempts to dominate the EU gas market. 
The idea of a peaceful, sustainable future of Europe as a whole has been deeply shattered by Ukrainian experience. This is particularly true of the post World War 2 security architecture established by the Final Act of the Conference on Security and Cooperation in Europe, 1975; the Paris Charter, 1990; the Budapest Memorandum, 1994; and the Fundamental NATO-Russia Act, 1997. All these agreements guarantee unequivocally the inviolability of borders in Europe. By invading Crimea (and effectively other parts of Ukraine) Putin has not only infringed on the sovereignty of that country, but simultaneously violated all four treaties [93]. If Putin's Russia continues to consider the USA and NATO as the main enemies, then neutralising the EU by making it energy-dependent on Russia is a priority that makes sense. In the present situation, with mutual sanctions in force both by the EU and Russia, a stronger and more credible EU energy security planning will be needed. The critical bottleneck within the EU will be not the electricity but the heating sector, which means that hardest hit, in case of gas supply disruption will be the civilians in the relevant EU countries. EU's policy frameworks need to put much more emphasis on energy efficiency and savings.

\section{References}

1. Branko Bošnjaković: Environment and climate change as geopolitical issues in the Asias: what can be learnt from the European experience? Globality Studies Journal, Issue 35, 26 July 2013

2. Branko Bošnjaković: Geopolitics of climate and energy: EU between ethics and security. Energy and the Environment (2014) 1-28

3. BBC News: Why did Copenhagen fail to deliver a climate deal? 22 December 2009. http://news. bbc.co.uk/2/hi/8426835.stm

4. Intergovernmental Panel on Climate Change, 2014, Working Group III, Mitigation of Climate Change. http://www.ipcc.ch/report/ar5/wg3/ 10.08.2014

5. Benito Müller, Niklas Höhne, Christian Ellermann: Differentiating (historic) responsibilities for climate change. Climate Policy, Volume 9, Issue 6, 2009

6. Kevin A. Baumert, Timothy Herzog, Jonathan Pershing: Navigating the numbers - Greenhouse gas data and international climate policy. World Resources Institute 2005, 31-33 http://pdf.wri. org/navigating_numbers_chapter6.pdf

7. Rob Dellink, Michel den Elzen, Harry Aiking, Emmy Bergsma, Frans Berkhout, Thijs Dekker, Joyeeta Gupta: Sharing the burden of financing adaptation to climate change, Global Environmental Change. Volume 19, Issue 4, October 2009, Pages 411-421

8. Rafael Leal-Arcas: The BRICS and Climate Change. International Affairs Forum, pp. 1-5, 2013

9. Branko Bošnjaković: Geopolitics of climate change: A review. Thermal Science 2012 Volume 16, Issue 3, Pages: 629-654

10. Renewable Energy: Policy Considerations for Deploying Renewables. International Energy Agency 2011, p. 26-30

11. Jonathan Holslag: China's scepticism of clean energy champion Europe. The International Spectator, Vol. 45, No. 1, March 2010, 75-89

12. Mehrunisa Malik: 'Bold Statements' and 'Intended Nationally Determined Contributions' (INDCs). LEAD Pakistan, June 26, 2014. http://www.lead.org.pk/lead/postDetail.aspx?postid=109 11.08.2014

13. UN Framework Convention on Climate Change: INDCs as communicated by Parties. http://www4. unfccc.int/submissions/INDC/Submission\%20Pages/submissions.aspx Accessed October 6, 2015.

14. The White House: U.S.-China Joint Presidential Statement on Climate Change. September 25, 2015.

15. Christian Speicher: Obama lässt seinen Worten Taten folgen. Neue Zürcher Zeitung, August 5, 2015, p. 3; 
16. Matthias Müller: China setzt sich ehrgeizige Ziele beim Klimaschutz. Neue Zürcher Zeitung, September 28, 2015.

17. Climate Action Tracker: Tracking INDCs. http://climateactiontracker.org/indcs.html Accessed October 7, 2015.

18. European Commission: A policy framework for climate and energy in the period from 2020 to 2030. COM(2014) 15 final, Brussels, 22.1.2014. See also European Commission Press Release: 2030 climate and energy goals for a competitive, secure and low-carbon economy. http://europa. eu/rapid/press-release IP-14-54 en.htm

19. 2030 Climate and Energy Policy Framework. European Council, Conclusions 23/24 October 2014. EUCO 169/14 CO EUR 13 CONCL 5. http://data.consilium.europa.eu/doc/document/ ST-169-2014-INIT/en/pdf

20. Grüne Energieziele für Frankreich. Neue Zürcher Zeitung, 31 July 2014, p. 21

21. Jan-Peter Eveleens, Louise van Schaik: De Europese worsteling met het klimaatpakket voor 2030. Internationale Spectator jaargang $68 \mathrm{nr} 7 / 8 .$, p. 9-13

22. Roadmap for moving to a low-carbon economy in 2050. 9.07.2014 http://ec.europa.eu/clima/ policies/roadmap/index en.htm

23. European Commission: Energy efficiency and its contribution to energy security and the 2030 Framework for climate and energy policy. COM(2014) 520 final, Brussels, 23.7.2014 See also Press Release: European Commission proposes a higher and achievable energy savings target for 2030. http://europa.eu/rapid/press-release IP-14-856 en.htm

24. Frankfurt School FS-UNEP Collaborating Centre: Renewable Energy Market Share Climbs Despite 2013 Dip in Investments. https://unfccc.int/files/press/releases/application/pdf/gtr press release_2.pdf

25. Pieter Boot, Jos Notenboom: De Duitse Energiewende: uitdagingen en lessen voor Nederland. Internationale Spectator jaargang $68 \mathrm{nr} 7 / 8$., p. 14-18

26. Institute of Energy Research IER: Germany's Green Energy Destabilizing Electric Grids, January 23, 2013. http://instituteforenergyresearch.org/analysis/germanys-green-energy-destabilizingelectric-grids/

27. Spain and Italy reduce feed-in tariffs. Sun\&Wind Energy, 26.06.2014. http://www.sunwindenergy. $\mathrm{com} /$ photovoltaics/spain-and-italy-reduce-feed-tariffs

28. "Britain sets out Europe's alternatives to Russia". Reuters, 20 March 2014

29. Wikipedia: Third Energy Package http://en.wikipedia.org/wiki/Third_Energy_Package

30. Regulation (EU) No 34 /2013 of the European Parliament and of the Council of 17 April 2013 on guidelines for trans-European energy infrastructure and repealing Decision 1364/2006/EC and amending Regulations (EC) 713/2009, (EC) 714/2009 and (EC) 715/2009

31. 'Gazprom clause' issues Russia ultimatum for energy co-operation. EurActiv, 20-09-2007 http:// www.euractiv.com/energy/gazprom-clause-issues-russia-ult-news-218748

32. In-depth study of European Energy Strategy. SWD(2014)330 final/3. European Commission, Brussels, 2.7.2014

33. European Commission: Communication from the Commission to the European Parliament and the Council. European Energy Security Strategy. Brussels, 28.5.2014, COM(2014) 330 final

34. Timothy Snyder : Putins Projekt. Frankfurter Allgemeine, 14.04.2014. http://www.faz.net/-hf27 ockg

35. „Putin deplores collapse of the USSR“, BBC News, 25 April 2005 (http://news.bbc.co.uk/2/ hi/4480745.stm)

36. Hans Rauscher: Putin will nicht nur die Ukraine wiederhaben - Putin handelt nach der klassischen Maxime der Zaren. Der Standard, 31 January 2014

37. Bernard Bridel: Le glacis de la Russie - la prise de contrôle de la Crimée rappelle combien Moscou veille à son « étranger proche ». Tribune de Genève, mercredi 5 mars 2014

38. Benjamin Triebe: Moskaus zweiter Streich. Neue Zürcher Zeitung, 26 August 2014. http:// webpaper.nzz.ch/2014/08/26/international/LHBHI/moskaus-zweiter-streich

39. Joschka Fischer: Die Ukraine - eine Tragödie in mehreren Akten. Der Standard, 3./4. May 2014, p. 31

40. Franziska Holz, Hella Engerer, Claudia Kemfert Philipp M. Richter, Christian von Hirschhausen: European Natural Gas Infrastructure: the Role of Gazprom in Natural Gas Supplies. DIW Berlin: Politikberatung kompakt 81. Berlin May 2014 
41. Leal-Arcas, R. and Filis, A. "The Energy Community and the Energy Charter Treaty: Special Legal Regimes, their Systemic Relationship to the EU, and their Dispute Settlement Arrangements," Oil, Gas \& Energy Law Journal, Vol. 12, Issue 2, pp. 1-42, 2014

42. John Vinocur: The EU goes after Gazprom. The New York Times, October 18, 2012. http://www. nytimes.com/2012/10/19/opinion/the-eu-goes-after-gazprom.html? r=0

43. European Commission - Press release. Antitrust: Commission sends Statement of Objections to Gazprom for alleged abuse of dominance on Central and Eastern European gas supply markets. 22 April 2015. http://europa.eu/rapid/press-release_IP-15-4828_en.htm. Accessed October 3, 2015.

44. Stockholm arbitration to hear Lithuania's claim against Gazprom next year. Delfi by the Lithuania Tribune. September 25, 2014. http://en.delfi.lt/lithuania/energy/stockholm-arbitration-to-hearlithuanias-claim-against-gazprom-next-year.d?id=65947694. Accessed October 3, 2015

45. Roman Kilisek: How Gazprom strives to cement its dominance in the European gas market. Breaking Energy, February 24, 2014. http://breakingenergy.com/2014/02/24/how-gazprom-strivesto-cement-its-dominance-in-the-european-gas-market/

46. Bendik Solum Whist: Nord Stream: not just a pipeline, Fridtjof Nansen Institute, November 2008

47. Robert L. Larsson: Nord Stream, Sweden and Baltic Sea Security. Swedish Defence Research Agency. ISSN 1650-1942. March 2007

48. Vladimir Socor: Germany in New Role as Transit Country for Russian Gas. Eurasia Daily Monitor Volume: 11 Issue: 29, February 13, 2014.

49. Hannah Cleaver: Putin delivers huge gas supply deal to 'key ally' Germany. The Telegraph 12 October 2006. http://www.telegraph.co.uk/news/worldnews/1531281/Putin-delivers-huge-gassupply-deal-to-key-ally-Germany.html

50. Marc Young: Schröder to build Putin's pipeline. Spiegel Online 12.12.2005

51. David Crawford, Thomas Catan: "Putin threatens to scrap gas pipeline as talks with EU leaders approach". The Wall Street Journal, November 13, 2008

52. Wikipedia: "Nord Stream". http://en.wikipedia.org/wiki/Nord Stream

53. Vladimir Socor: Nord Stream-OPAL-Gazelle: Another Ukraine-Bypass Route for Gazprom. Eurasia Daily Monitor Volume: 11 Issue: 22, February 4, 2014.

54. "New twists and turns in German-Russian gas pipeline saga". Deutsche Welle,13.7.2007 http:// www.dw.de/new-twists-and-turns-in-german-russian-gas-pipeline-saga/a-2679905

55. Vladimir Socor: Gazprom Accumulates Storage Capacities in Germany. Eurasia Daily Monitor, Volume: 11, Issue: 28. February 12, 2014.

56. Vera Eckert: "Germany rules favourably on OPAL gas pipeline" 25.2.2009 Finanz Nachrichten/ Reuters, http://www.finanznachrichten.de/nachrichten-2009-02/13209704-germany-rulesfavourably-on-opal-gas-pipeline-020.htm

57. "He who pays for the pipelines calls the tune", Economist, 16.07.2009 http://www.economist. com/node $/ 14041672$

58. Sergio Metalucci: Week 29 Overview. Natural Gas in Europe, July 20, 2014. http://www. naturalgaseurope.com/europe-natural-gas-week-29-overview

59. Slovak PM calls Nord Stream expansion deal 'a betrayal'. EurActiv 10 September 2015. http:// www.euractiv.com/sections/energy/slovak-pm-calls-nord-stream-expansion-deal-betrayal-317531

60. Slovakia, Poland against construction of Nord Stream 2 pipeline: presidents. China-Europe, 3 October, 2015. http://news.xinhuanet.com/english/2015-10/03/c_134680708.htm

61. Wikipedia: "South Stream". http://en.wikipedia.org/wiki/South_Stream

62. Valentina Pop: Energy security: South Stream vs. Nabucco gas pipelines. South East European Times, 14 February 2008. http://www.setimes.com/cocoon/setimes/xhtml/en_GB/features/setimes/ features/2008/02/14/feature-02

63. ENI calls for South Stream, Nabucco links. UPI, 11 March 2010. http://www.upi.com/ Science News/Resource-Wars/2010/03/11/ENI-calls-for-South-Stream-Nabucco-links/UPI96591268317232/

64. Margarita Assenova: Gazprom Agreements on South Stream Breach EU Law; Bulgaria and Serbia Ask EU to Negotiate with Russia. Eurasia Daily Monitor ,Volume: 10 Issue: 220 December 9, 2013.

65. EurActiv: Oettinger takes lead in legal spat with Russia over South Stream. Natural Gas Europe. December 13, 2013. http://www.naturalgaseurope.com/oettinger-legal-dispute-with-russia-oversouth-stream 
66. Margarita Assenova: South Stream: Bypassing Ukraine and Dividing the EU. Eurasia Daily Monitor, Volume: 11 Issue: 83, May 5, 2014.

67. Joint motion for a resolution. European Parliament 16.4.2014. http://www.europarl.europa.eu/ sides/getDoc.do?pubRef=-//EP//TEXT+MOTION+P7-RC-2014-0436+0+DOC+XML+V0//EN

68. South Stream gas pipeline: European endpoint in Austria. OMV.com, April 29. http://m.omv. com/generic-list/display/en/125575886757041

69. Rudolf Hermann: Das South Stream-Projekt spaltet Bulgariens Regierungskoalition. Neue Zürcher Zeitung, 12 June 2014

70. TASS Russian News Agency: Bulgaria suspends work on South Stream project on EU recommendation. August 19, 2014. http://tass.ru/en/economy/745736

71. EU to Probe Serbia's South Stream Deal. BalkanInsight, 25 April 2014. http://www.balkaninsight. $\mathrm{com} / \mathrm{en} /$ article/eu-to-examine-serbia-s-south-stream-deal

72. Serbia will never join any sanctions against Russia. b92, April 30, 2014 http://www.b92.net/eng/ news $/$ politics.php? yyyy $=2014 \& \mathrm{~mm}=04 \& \mathrm{dd}=30 \&$ nav id $=90153$

73. Radio Free Europ- Radio Liberty: Serbia Says It Will Be Forced To Suspend South Stream Construction. October 04, 2015. http://www.rferl.org/content/serbia-says-it-will-be-forced-tosuspend-south-stream-construction/25415286.html

74. Russia drops South Stream gas pipeline plan. BBC News, 1 December 2014. http://www.bbc. com/news/world-europe-30283571 Accessed October 4, 2015.

75. Emanuele Scimia: South Stream's Demise Shakes up Italian-Russian Relations. Eurasia Daily Monitor, Volume: 11, Issue: 218. December 8, 2014.

76. Orhan Gafarli: Russian Energy Proposals for Turkey Could Undermine Southern Gas Corridor. Eurasia Daily Monitor, Volume: 11, Issue: 225. December 17, 2014.

77. Stephen Blank: Russia Gives EU, Turkey and Azerbaijan an Ultimatum on 'Turk stream'. Eurasia Daily Monitor, Volume: 12, Issue: 13. January 14, 2015.

78. Wikipedia: "Trans-Anatolian gas pipeline". https://en.wikipedia.org/wiki/Trans-Anatolian_gas_ pipeline

79. Vladimir Socor: More Competition, Less Expensive Russian Gas in Ukraine's Market. Eurasia Daily Monitor, Volume: 12, Issue: 62, April 3; Issue: 63, April 6; and Issue: 65, April 8, 2015.

80. Edward C. Chow, Michael Lelyveld: Russia-China Gas Deal and Redeal. Center for Strategic and International Studies. May 11, 2015. http://csis.org/print/55622

81. Orhan Gafarli: Will Turkey Choose the European or Eurasian Energy Union? Eurasia Daily Monitor, Volume: 12, Issue: 72. April 17, 2015.

82. Stephen Blank: Russia's New Energy Accords: Are They for Real? Eurasia Daily Monitor, Volume: 12, Issue: 123. July 1, 2015.

83. Andrew Jay Rosenbaum: SOCAR Turkey CEO: TANAP to create 15,000 jobs. Anadolu Agency. 3 July 2015. http://www.aa.com.tr/en/economy/socar-turkey-ceo-tanap-to-create-15-000-jobs/29862

84. Philipp Richter, Franziska Holz: All quiet on the Eastern Front? Disruption scenarios of Russian natural gas supply to Europe. Discussion Paper 1383, DIW Berlin, May 26, 2014

85. László Marácz: Hongaarse parlementsverkiezingen 2014: Orbán mag door met zijn herstelbeleid. Internationale Spectator, June 2014, Jaargang 68 nr. 6 p. 2-7

86. Rudolf Hermann: Rumänien geht auf mehr Distanz zu Russland. Neue Zürcher Zeitung, 5 August 2014, p. 6

87. Alexa Piccolo: The Internal Dimension of the European Energy Security Policy. EUCERS Newsletter, Issue 25, June/July 2013 http://www.kcl.ac.uk/sspp/departments/warstudies/research/ groups/eucers/newsletter25.pdf

88. European Parliament 2014-2019. DRAFT REPORT on European Energy Security Strategy (2014/2153(INI)) Committee on Industry, Research and Energy. Rapporteur: Algirdas Saudargas. 2014/2153(INI) 11.12.2014.

89. Miroslav Poche, Ashley Fox and Neoklis Sylikiotis: EU energy security strategy fails to secure parliament's support. The Parliament Magazine. 12 June 2015. https://www.theparliamentmagazine. eu/articles/opinion/eu-energy-security-strategy-fails-secure-parliaments-support

90. Donald Tusk: A united Europe can end Russia's energy stranglehold. Financial Times, April 21, 2014 
91. European Commission - Press release. Energy Union: secure, sustainable, competitive, affordable energy for every European. Brussels, 25 February 2015. http://europa.eu/rapid/press-release_IP15-4497 en.htm

92. 'It seems solar and wind power may become the United States largest renewable energy source'. Pvbuzz, August 5, 2014. http://www.pvbuzz.com/solar-and-wind-power-largest-renewableenergy-source/

93. Study confirms China's solar world dominance. PVTECH, 11 August 2014. http://www.pv-tech. org/news/study_confirms_chinas_solar_world_dominance

94. Michael Thumann: Der Entfesselte. Die Zeit, $\overline{4}$ September 2014, p. 3 
Branko Bošnjaković

\title{
Europa između klimatskih promjena i energetske nesigurnosti: geopolitički aspekti
}

\begin{abstract}
Sažetak
EU vidi sebe kao svjetskog predvodnika pri odgovoru na izazove klimatskih promjena. Nedavno je ukrajinska kriza ukazala na ranjivost opskrbe energijom kao posljedicu ovisnosti EU o uvozu nafte i plina. Rad razmatra povezanost i izglede klimatske i energetske politike EU s obzirom na etičke i sigurnosne dimenzije. Etička dimenzija raspravlja se u odnosu na pravednu globalnu alokaciju odgovornosti - između pojedinih regija ili država - za smanjivanje emisija stakleničkih plinova, što će biti i glavna tema nadolazećeg UN sastanka na vrhu u Parizu. No istovremeno bi i temeljne vrijednosti EU mogle doći u pitanje ukoliko se ne bi jamčila i sigurnosna dimenzija svih zemalja članica. Etički i sigurnosni izazovi s kojima je EU suočena, jasno ukazuju na poželjnost ubrzanog uvođenja niskougljičnog gospodarstva i odgovarajuće infrastrukture, pri čemu obnovljivi izvori energije trebaju igrati ključnu ulogu, i to srednje- i dugoročno. Već površan pogled na postojeću literaturu pokazuje da trajna ovisnost o uvozu nafte i plina, posebice iz Rusije, predstavlja ekonomski, politički i okolišni rizik. Autor daje pregled i kritičko vrednovanje nekih predloženih odgovora na te izazove, kao što je stvaranje Energetske unije EU.
\end{abstract}

Ključne riječi: Klima, Energija, EU, Geopolitika. 